ARTICLE HISTORY: Received: May 19, 2021 Accepted: July 12, 2021 Published: July 19, 2021

\title{
CULTIVATING PRESIDENT HO CHI MINH'S WORKING STYLE FOR POLITICAL CADRES IN THE MILITARY ACADEMIES AND OFFICER TRAINING SCHOOLS OF THE PEOPLE'S ARMY OF VIETNAM
}

\author{
Phung Quang Hung \\ Postgraduate student \\ Tran Quoc Tuan University \\ Hanoi, Vietnam

\section{РАЗВИТИЕ РАБОЧЕГО СТИЛЯ ПРЕЗИДЕНТА ХО ШИ МИНА ДЛЯ ПОЛИТИЧЕСКИХ КАДРОВ В ВОЕННЫХ АКАДЕМИЯХ И ШКОЛАХ ОФИЦЕРНОЙ ПОДГОТОВКИ НАРОДНОЙ АРМИИ ВЬЕТНАМА} \\ Пхунг Куанг Хунг \\ Аспирант \\ Чан Куок Туан Университет \\ Г. Ханой, Вьетнам
}

\begin{abstract}
Ho Chi Minh's working style includes a scientific and systematic method, way, and policy of working expressed in leadership and management activities to accomplish the goals and tasks of the revolution. It shows the specificity and profound content. It is also a foundation for cadres to study, practice, and cultivate their style, revolutionary moral qualities, and professional competence. The article will analyze and clarify crucial aspects, including Ho Chi Minh's working style and political cadres in the Vietnamese People's Army's military academies and officer training schools. From there, the author offers some suggestions for cultivating Ho Chi Minh's working style for political cadres in the coming time.

Аннотация. Стиль работы Хо Ши Мина включает научный и систематический метод, способ и политику работы, выраженную в лидерстве и управленческой деятельности для достижения целей и задач революции. В нем проявляется специфика и глубокое содержание. Это также основа для изучения, практики и развития своего стиля, революционных моральных качеств и профессиональной компетентности. В статье будут проанализированы и прояснены важнейшие аспекты, в том числе стиль работы Хо Ши Мина и политические кадры в военных академиях Вьетнамской народной армии и школах подготовки офицеров. Отсюда автор предлагает несколько предложений по стилю работы Хо Ши Мина для политических кадров на ближайшее время.

Key words: Vietnam, Ho Chi Minh, Working style, Vietnam People's Army, Vietnamese military academies

Ключевые слова: Вьетнам, Хо Ши Мин, стиль работы, вьетнамская народная армия, вьетнамские военные академии.
\end{abstract}

Ho Chi Minh's style is the embodiment of humanity's highest aspirations. The $24^{\text {th }}$ session Resolution of General Assembly of the United Nations affirmed that: "Ho Chi Minh, a great symbol of the determination of an entire nation, devoted his life to the cause of national liberation of the Vietnamese, and contributed to the common struggle of nations for peace, national independence, democracy, and social progress. President Ho Chi Minh's important contributions to culture, education, and art are crystallized by Vietnamese cultural tradition for thousands of years. His thoughts express the peoples' aspirations to affirm their national identity and represent mutual understanding." [7, p.144].

\section{Ho Chi Minh's working style}

Style is a feature of living and working, so it has a strong personality. In a book titled "Ho Chi Minh's method and style", Prof. Dr. Dang Xuan Ky has outlined the main contents of President Ho Chi Minh's working style, namely mass style, collective and democratic style, and scientific working style. He also stated that: "Ho Chi Minh's working style not only impacts perception but also touches the heart. Thanks to Ho Chi Minh's working style, people join the Party and embrace its leadership not only with their reason but also with their profound sentiments" [1, p.179-180]. Besides, when researching the style of Ho Chi Minh, Prof. Dr. Mach Quang Thang affirmed that: "Ho Chi Minh's style, which has its unique and systematic characteristics, become a stable routine reflected in his entire life" [6, p.82].

Ho Chi Minh's style includes the thinking style, expression style, working style, behavior style, and lifestyle. In particular, it is a unique factor that shapes his personality in revolutionary activities. Besides, it reflects the core values of his ideology and morality in a vivid, natural, and unique way. Moreover, it directly contributes to determining the quality and efficiency of work and dramatically influences cadres, party members, the people, and international friends. Ho Chi Minh's working style is shown in the following contents: 
Firstly, it's a democratic working style.

Democratic working style is one of the critical points in Ho Chi Minh's working style. Its foundation is to respect the people's mastery, wholeheartedly serve them, listen to their opinions, create good relations with them, learn from them, and be under their supervision. With this view, Ho Chi Minh demands that the people elect the governments from the commune to the central level. The government needs to be loyal, dedicated, and diligent to the people. Cadres, who are organized, inspected, and supervised by the people, must know how to work for their benefit. If cadres listen to the people's suggestions to correct mistakes, this democracy is actual, not formal and nominal.

According to Ho Chi Minh, the democratic working style requires cadres to stick with, respect, and put themselves in the collective's place. They need to listen to opinions and develop the strength of the collective. The most important thing is that they mustn't consider themselves above the organization and stand outside its inspection and supervision. They have to consult with the team to be able to make the most accurate and timely decisions. Cadres need to expand democracy to promote collective strength to reach a suitable working method. They shall discuss, unite, and be determined, and avoid the situation of "the left-hand doesn't know what the right hand is doing" [5, p. 25] to successfully carry out the set tasks. Accordingly, the democratic working style should be expressed from significant to small issues in all aspects. In which, the leading cadres must take responsibility, complete the tasks assigned, and adhere to the principle of democratic centralism, collective leadership, and individual in charge in the spirit of: "The collective leadership is democracy. The individual in charge is central. If "Collective leadership" is combined with "individual in charge," democratic centralism is formed. Working in the wrong way is contrary to the democratic centralism" [3, p. 620].

Secondly, it's the mass working style.

The mass working style is a fundamental and pervasive feature in the whole life of Ho Chi Minh. This style is expressed in the closeness to reality, trust, and respect for people. It is also presented in listening to opinions, dealing with honest recommendations, accepting criticisms of the people, and correcting all shortcomings. With a style that is close to the people and for their sake, listening to their ideas, and pursuing the correct way, Ho Chi Minh is an exemplary example of the close relationship that rarely occurs between leaders and the people.

According to Ho Chi Minh, the masses have created history, and revolution is their cause. With the policy of relying on the people and promoting the strength of national unity to develop and protect the country, he affirmed that "the country considers the people its foundation" [3, p. 501], "If the foundation is strong, the country will be power. We will create victory thanks to the strength of the people" [3, p. 502]. "Therefore, if we discover that the methods we organize and work are unsuitable for the masses, we should be brave to ask the leadership to remove or modify them" [3, p. 286]. Ho Chi Minh also often requires cadres and party members " to consider the masses the starting point and the highest goal of all undertakings and policies" [3, p. 330]. He repeatedly criticizes cadres who are not close to "haughty when being revolutionaries" [2, p. 20] and don't consider themselves servants and students of the people. Ho Chi Minh always paid attention to thoughts and aspirations and sincerely cared about all aspects of people's life. He believed, respected, listened to, and resolved their honest suggestions. Moreover, he also received opinions, corrected shortcomings, educated, led, learned, and respected their mastery.

Thirdly, it's the scientific working style.

The attraction and persistence of Ho Chi Minh's style to the Vietnamese and international revolutions are built by his scientific working style. Ho Chi Minh's scientific working style has a tight coherence and harmony between theory and practice, between words and actions. As a result, each Vietnamese, regardless of position, can study and follow his approach. He criticized the following phenomena: working on feelings and working subjectively and negligently, trying to finish the tasks without caring about their quality and efficiency, implementing freely and arbitrarily and ignoring investigation and planning, working slowly and not respecting time, effort, and wealth, and working without practicality and vision. Therefore, Ho Chi Minh requires cadres and party members to develop a scientific way of work and leadership, which focuses on the following main points: working with purpose, being consistent between plans, measures, and determination, carefully investigating and studying before implementing, and regularly summarizing, learning experience, checking and supervising after finishing tasks.

Fourthly, it is to set an example while working.

Ho Chi Minh is a strong believer in setting a good example. He stated that one of the great methods to strengthen the Party and socialist people was to offer an example of good people and good acts every day to educate each other. According to Ho Chi Minh, cadres and party members must be examples from small tasks to important ones. They need to be diligent, economical, honest, frank, public-spirited, and to talk the talk and walk the walk. He asked all cadres and party members to set examples of morals. He reminded cadres and party members that: "Being in front of the masses, it's not true that if we write the word "communist" on our foreheads, they love us. They only love people who possess moral character. To guide the people, we must set a standard for them to imitate" [4, p. 16]. If we are honest, we can make others honest. It will be preposterous if we are not upright but whishing others to be upright.

Therefore, Ho Chi Minh's life is a combination of thought and action with exemplary practice. He is a pure and complete example. Besides, he is an example of striving and sacrificing for national liberation and liberating classes, people, and humanity. Ho Chi Minh is considered an example of diligence, thrift, purity, frankness, impartiality, pure 
private life, simple lifestyle, and modesty. In addition, he is well known as an example of strong will and energy, overcoming all challenges and difficulties to achieve the revolutionary goal. Furthermore, he is an example of trusting in the strength of the people, respecting and wholeheartedly serving them. Finally, he is a benevolent, selfless, tolerant, benevolent person who does his best for others.

According to Ho Chi Minh, setting an example should be implemented based on three aspects: ourselves, other people, and our work. We must not be conceited, self-satisfied, and arrogant. Besides, we must learn, self-criticize, correct the wrong things and criticize every day. We must keep sincerity, humility, solidarity, honesty, tolerance, and graciousness for other people. For our work, we must keep the principles and prioritize the official task in all situations.

President Ho Chi Minh says that if we want to become an example, we must talk the talk and walk the walk that is a standard in traditional ethics and a minimum standard of public service ethics. For cadres and party members, the close unity between words and actions, between ethics and setting examples of morals should be consistent in work and private life, between the leader's ethics and ethics in daily life. The higher the position is, the greater the prestige is. Therefore, we have to make every effort to perfect our morality and be consistent between our words and actions. He asked each cadre and party member to be a model in work and life. Moreover, they must talk the talk and walk the walk for the masses to follow.

Parents should be examples for their children, and the older brothers and sisters should be examples for the young. At schools, teachers serve as role models for students. In agencies and organizations, the leader is an example for employees, and this person can be an example for others. In daily life, cadres and party members are responsible for self-cultivation to have a pure personal life and become examples for the people. Thereby, they can increase the right and good things and fight against the vices.

In setting an example, cadres and party members must always set an example of the spirit of serving the people. Thus, from a profound philosophy, Ho Chi Minh emphasized the responsibility to serve the people. He said that we had to compensate the people appropriately because our food and clothes came from their efforts and sacrifices. Therefore, cadres and party members must be enthusiastic, exemplary, and responsible to the people in terms of their words and actions.

Lastly, it's a style of talking the talk and walking the walk.

"Talking the talk and walking the walk" shows the unity between theory and practice, thought and action, and perception and deed. To unify words and actions, each person must have the proper awareness and determination to overcome himself in all circumstances.

According to Ho Chi Minh, "talking the talk and walking the walk" are not only moral principle, reason of life, and action guideline, but also a vivid and concrete expression of deeply mastering the rule of unity between theory and practice, between thought and action, between moral thought and ethical behavior of each person. Officials must master under the guidelines and policies of the Party and laws of the State. They are not allowed to "speak one way and act another" [4, p. 433] and promise empty words.

2. The contingent of political cadres at the military academies and officer training schools of the People's Army of Vietnam

President Ho Chi Minh has emphasized the importance of the contingent of cadres. He believes that "cadres are the origin of all work" [3, p. 309], and "the success or failure of work is determined by their quality" [3, p. 313]. Therefore, cultivating Ho Chi Minh's working style for political cadres at the military academies and officer training schools of the People's Army of Vietnam is extremely important.

The team of political cadres at the military academies and officer training schools of the People's Army of Vietnam is a part of the contingent of cadres of the Communist Party of Vietnam. Each unit has its characteristics in each period due to the requirements of building an army, academies, officer training schools, and defined responsibilities and duties. However, they work under political agencies of academies and officer training schools of the People's Army of Vietnam and play a fundamental role in advising the Party committees, standing committees, political commissars of academies, and officer training schools on guidelines and measures to lead and direct party and political work. At the same time, they will well guide, direct, inspect, and urge agencies, faculty of teachers, and units to conduct party and political work according to the assigned responsibilities, duties, and scope of authority. In addition, they also participate in the development and implementation of general work plans of political agencies, academies, and officer training schools of the People's Army of Vietnam.

Cultivating Ho Chi Minh's working style for political cadres at the military academies and officer training schools of the People's Army of Vietnam has brought many achievements in recent years. It has contributed to forming and training Ho Chi Minh's working style for this team. In addition, it has helped them supplement and develop their knowledge, quality, capacity, and working style. Moreover, this activity also strengthens, develops, and perfects the working style of political cadres at the military academies and officer training schools of the People's Army of Vietnam, helping them meet the mission's requirements and fulfill the assigned responsibilities and tasks.

However, under the negative impact of the market economy and processes of globalization, some political cadres have not resolutely criticized and fought against wrong views. Moreover, they have not actively researched and 
attempted to tackle work-related challenges. As a result, the practical capacity, forecasting ability, adaptability skills, and problem-solving skills of a few political cadres are still limited.

3. Some solutions for cultivating Ho Chi Minh's working style for political cadres at the military academies and officer training schools of the People's Army of Vietnam

It is imperative to implement the following solutions to train Ho Chi Minh's working style for political cadres.

Firstly, we shall create a drastic change in awareness and responsibility of organizations and forces in cultivating Ho Chi Minh's working style for political cadres at the military academies and officer training schools of the People's Army of Vietnam. It is the primary, transparent, and leading solution that determines the quality and effectiveness of this task. Moreover, perception plays a vital role in life because it directs all human activities. Only when a person has the correct perception, can he take high responsibility and act scientifically, correctly, and effectively.

Secondly, strengthening the leadership, direction, and guidance of party committees, party organizations, political commissars, politicians, commanders, and political agencies plays a critical part in cultivating Ho Chi Minh's working style for political cadres. Moreover, it is an important method that shows the Party's viewpoint on promoting synergy in this activity.

Thirdly, we shall determine the right content and apply flexibly and creatively forms and measures in training Ho Chi Minh's working style for political cadres. It is considered an essential and breakthrough solution, determining the results of this task at present. Therefore, it can be said that concretizing, determining the right content, and flexibly and creatively applying measures is an urgent requirement.

Fourthly, we need to improve the qualifications and capacity of lecturers, reporters, and propagandists who will train Ho Chi Minh's working style for political cadres. It will directly contribute to improving the quality and efficiency of this mission. Furthermore, it is crucial to value the role of these people because they are the core forces and directly conduct training activities.

Fifthly, it is vital to promote the positivity and self-discipline of political cadres in self-improving and training Ho Chi Minh's working style. Thanks to that, we can enhance the subjective factor that determines the effectiveness of this task. Only if party members actively and voluntarily turn the training process into a self-training and self-cultivation for themselves and the whole team, can cultivating Ho Chi Minh's working style achieve greater efficiency.

Lastly, we must strengthen the role of the pedagogical environment and cultural institutions in cultivating Ho Chi Minh's working style for political cadres, which is also a meaningful solution, promoting, supporting, and creating a formal environment in which Ho Chi Minh's working style can be formed, perfected, and developed.

\section{Conclusion}

Ho Chi Minh's working style is a beautiful blend of traditional Vietnamese cultural values and the quintessence of human culture based on Marxism's dialectical materialism and the outstanding qualities of a leader committed to the country and the people, creating an enduring vitality for all generations. The revolutionary reality of Vietnam and the world possesses constant changes in the geo-political-economic relations between countries and territories. Besides, the influence of the Fourth Industrial Revolution and the expanding international integration of Vietnam have resulted in a shift in foreign relations. Therefore, political cadres in the People's Army of Vietnam's military academies and officer training schools must cultivate and develop political and moral qualities and a pure and straightforward lifestyle. They must constantly be close to the people and consider the people's interests the driving force for their actions. Cultivating Ho Chi Minh's working style is the best way to strengthen the people's belief in cadres and party members and the relationship between the Communist Party of Vietnam and the Vietnamese. It is also the immediate and long-term task for the Vietnamese revolution currently.

\section{REFERENCES}

1. Dang Xuan Ky. Ho Chi Minh's Method and Style. Hanoi: National Political Publishing House, 2010.

2. Ho Chi Minh. Complete Works. Volume 4. Hanoi: Truth National Political Publishing House, 2011.

3. Ho Chi Minh. Complete Works. Volume 5. Hanoi: Truth National Political Publishing House, 2011.

4. Ho Chi Minh. Complete Works. Volume 6. Hanoi: Truth National Political Publishing House, 2011.

5. Ho Chi Minh. Complete Works. Volume 13. Hanoi: Truth National Political Publishing House, 2011.

6. Mach Quang Thang. Ho Chi Minh accompanies the nation. Hanoi: Ho Chi Minh City General Publishing House, 2017.

7. UNESCO. Resolution 24C/18.65 of UNESCO on the celebration of the 100th anniversary of President Ho Chi Minh's birthday, citing a new translation by the Ho Chi Minh Museum and UNESCO in Vietnam, 2019. 